\title{
A Short Statistical Sketch of the Child Labour Market in Mid-Nineteenth Century London
}

Tableau statistique du marché du travail des enfants à Londres au XIXe siècle

Peter Kirby

\section{CpenEdition}

\section{Journals}

\section{Electronic version}

URL: http://journals.openedition.org/rfcb/1606

DOI: $10.4000 /$ rfcb.1606

ISSN: 2429-4373

\section{Publisher}

CRECIB - Centre de recherche et d'études en civilisation britannique

\section{Printed version}

Date of publication: 1 September 2003

ISSN: 0248-9015

\section{Electronic reference}

Peter Kirby, "A Short Statistical Sketch of the Child Labour Market in Mid-Nineteenth Century London », Revue Française de Civilisation Britannique [Online], XII-3 | 2003, Online since 01 September 2003, connection on 20 April 2019. URL : http://journals.openedition.org/rfcb/1606 ; DOI : 10.4000/ rfcb.1606

This text was automatically generated on 20 April 2019.

\section{(c) $($ ) $\odot \odot$}

Revue française de civilisation britannique est mis à disposition selon les termes de la licence Creative Commons Attribution - Pas d'Utilisation Commerciale - Pas de Modification 4.0 International. 


\title{
A Short Statistical Sketch of the Child Labour Market in Mid- Nineteenth Century London
}

Tableau statistique du marché du travail des enfants à Londres au XIXe siècle

\author{
Peter Kirby
}

\section{AUTHOR'S NOTE}

The author wishes to thank Prof. M.E. Rose for bibliographical guidance and $\mathrm{Mr}$ R. Lovejoy for transcribing the census occupation tables for London.

1 The distinctiveness of the nineteenth-century London labour market has long been adverted to by scholars of economic and social history. However, the importance of London to British economic development has remained relatively under-researched compared with the great northern cotton and coal districts that characterised the 'classic' Industrial Revolution. ${ }^{1}$ Child employment in nineteenth-century London has also received relatively little attention compared with the larger number of studies of industrial child labour. ${ }^{2}$ Indeed, references to child labour in the metropolis continue to rely largely upon stereotypes of exploited or destitute children drawn from the works of social commentators such as Henry Mayhew or from the records of child protection charities such as Dr Barnardo's. ${ }^{3}$ Such records have inherent difficulties because social commentators sought to highlight the very poorest of working children whom they regarded as a serious social problem. Their accounts do not reflect the generality of metropolitan child labour. Mayhew's primary concern, for example, was for 'that class of poor whose privations seemed to be due to the insufficiency of their wages'. ${ }^{4}$ This brief study employs mid-nineteenth century census evidence to sketch out the major divisions of the London child employment market and asks how different London was from the rest of England and Wales. The emphasis is upon occupations that contained the largest absolute numbers of children and those that had exceptionally youthful age structures. 
2 The diversity of nineteenth-century metropolitan labour presents intractable problems in the use of aggregate census employment statistics. The London labour market was fundamentally different to that of the rest of England and Wales. The major differences were the relative absence of agriculture and large manufacturing and primary industries and the greater importance of domestic and retail services, clerical work, communications, workshops and handicrafts. ${ }^{5}$ Moreover, the association of particular forms of manufacture or service with specific metropolitan localities resulted in the understatement of some occupations. The London labour market comprised West End and East End clothing centres, furniture making in Tottenham Court Road, printing around Fleet Street, jewellery and precious metals in Clarkenwell and Hatton Garden, piano making in Camden Town, boot and shoe making in Bethnal Green, Shoreditch, Stepney and Hackney, as well as an enormous variety of smaller businesses. ${ }^{6}$ Also hidden within or absent from the aggregate statistics were the many small sweated industries and other dispersed forms of domestic work. These included small but notorious child occupations such as lucifer match-making and splint cutting that were concentrated around the poorer districts of Bethnal Green and Whitechapel. ${ }^{7}$ The 'strikingly' high metropolitan adult wage rates present additional difficulties to the scholar of child labour because high real wages for parents tend to be associated with a lower marginal value of child earnings and were likely to have been associated with lower levels of child labour. ${ }^{8}$

3 The 1851 census was the first to tabulate workers in specific occupations by quinquennial age groups (0-4, 5-9, 10-14, et seq.). The summary tables, however, are beset with enumeration problems. For example, the census tabulated children's work within an overwhelmingly 'adult' taxonomy of occupations which does not reflect the 'transitional' nature of many child occupations. Higgs has pointed out that 'occupations were also social designations reflecting status and perceived social worth'. The ascription of an adult occupation designation to a subordinate son, daughter or apprentice may have appeared strange to householders when asked to enter their children's occupations on the manuscript returns. This may have resulted in under-enumeration of child employment especially within certain skilled occupations. Assumptions made by the General Register Office about the different roles of males and females also prove problematical to the researcher. Distinctions between the different categories of domestic service (the largest employment group for female workers in London) in the summary tables relied very largely upon subjective decisions by the census checkers at the GRO. As Tillott pointed out, youthful female servants were recorded 'throughout the returns as house servants, maid servants, maids of all work, and under a dozen or more other names and grades down to plain "servant" '. ${ }^{10}$ The summary tables also contain a number of jobs that were wholly genderspecific. No males were tabulated as artificial flower makers, bonnet makers, cap makers, shawl makers, staymakers or pin makers (though both sexes were represented in needle making). Similarly, no females can be found listed as carpet makers, chimney sweepers or paper stainers. Such gendered assumptions are evident in the structure of the 1851 tables which contained 332 discrete male occupations but only 197 for females. ${ }^{11}$

4 The occupational complexity of London, therefore, together with the many problems of faulty enumeration and aggregation in the census, prevent any claim to accuracy in respect of actual numbers of children employed. Nonetheless, it is possible to examine differences in orders of magnitude between occupations of children in London and elsewhere and to examine generally the distinctiveness of the metropolitan child labour market compared with the rest of England and Wales. 


\section{The metropolitan child labour market in 1851}

Perhaps the most striking aspect of the metropolitan child labour market in 1851 was the small proportion of London children actually enumerated with an occupation compared with the rest of England and Wales (Table 1).

Table 1. Proportions (\%) occupied by sex and age-groups: London and England and Wales, $1851 .{ }^{12}$

\begin{tabular}{|c|c|c|c|c|}
\hline \multicolumn{5}{|l|}{ AGE GROUPS } \\
\hline & all ages & 5-9 & $10-14$ & $15-19$ \\
\hline \multicolumn{5}{|l|}{ Males } \\
\hline London & 64.54 & 0.32 & 22.91 & 82.45 \\
\hline$(\mathrm{E}+\mathrm{W})$-London & 65.96 & 2.59 & 41.58 & 90.91 \\
\hline \multicolumn{5}{|l|}{ Females } \\
\hline London & 32.52 & 0.21 & 11.86 & 56.49 \\
\hline$(\mathrm{E}+\mathrm{W})$-London & 31.42 & 1.91 & 24.24 & 64.50 \\
\hline
\end{tabular}

Source: Census 1851. PP 1852-53, LXXXVIII, Pt.I, England and Wales Summary Tables, xxv, xxvi, pp. ccxxii-ccxxvii; Population Tables II, London Tables, pp. 10-15.

In London, only 0.3 per cent of boys aged 5-9 and 23 per cent of boys aged 10-14 had a recorded occupation compared with 3 per cent and 42 per cent in the remainder of England and Wales. Among females, only 0.2 per cent aged 5-9 and 12 per cent aged 10-14 had a recorded occupation compared with 2 per cent and 24 per cent in the rest of England and Wales. The proportion of London males and females occupied at age 10-14 was around half the national average. The metropolis, therefore, harboured very low relative levels of child employment. Indeed, London (containing 11 per cent of the total of 10 to 14 year-olds in England and Wales) exerted an important depressive effect on national child labour rates (for example, the simple subtraction of London child labour statistics from the national statistics raises the proportion of occupied males aged 10-14 in the rest of England and Wales from 40 to 42 per cent). ${ }^{13}$

7 The sexual division of the metropolitan child labour market was also striking and mirrored prevailing cultural assumptions about the employment roles of males and females. Boys were assumed to be working outside the home for a small income whereas the natural place for girls was assumed to be the domestic sphere. This tendency was described aptly by Mayhew in the early 1850s when he observed that 'the boy is far more the child of the streets than is the girl'. ${ }^{14}$ Indeed, much of the general shortfall in the enumeration of female occupations compared with males is thought to have resulted from the tendency of females to work in 'unofficial' domestic labouring tasks. Girls between the ages of nine and 15 were frequently called upon to care for young children in 
their own homes or in those of relatives to allow mothers to perform work outside the home.

8 Gender differences are clearly reflected in the statistics of the most important metropolitan child occupations. In London, 45 per cent of employed males aged 10-14 were enumerated as errand-runners, messengers or porters compared with less than one per cent of females, whereas 59 per cent of London girls aged 10-14 were in some form of domestic service compared with only 5 per cent of males. The workshop and handicraft sectors employed about a quarter of the totals of occupied male and female children respectively, though females were numerically less important in this sector and tended to be found in the less-skilled operations for lower pay. The further major area of metropolitan child employment was in the retail, foodstuffs and hostelry trades in which about 10 per cent of child workers of both sexes were recorded (Table 2).

Table 2. Percentage of working children aged $10-14$ by occupation group, Census $1851 .{ }^{15}$

\begin{tabular}{|l|l|l|l|l|}
\hline & \multicolumn{2}{|l|}{ London } & \multicolumn{2}{l|}{$\begin{array}{l}\text { England } \\
\text { Wales } \\
\text { (minus London) }\end{array}$} \\
\hline & Males & Females & Males & Females \\
\hline N= & 24,569 & 12,948 & 356,225 & 203,685 \\
\hline Percentages & & & & \\
\hline Agriculture, animals and fisheries & 1.6 & 0.1 & 36.9 & 23.0 \\
\hline Workshops and handicraft & 23.7 & 27.6 & 17.3 & 22.7 \\
\hline Factory & 1.5 & 0.5 & 15.9 & 25.6 \\
\hline Transport and communications & 45.2 & 0.6 & 9.1 & 1.1 \\
\hline Mines and quarries & 0.3 & 0.0 & 9.4 & 0.9 \\
\hline Indefinite occupation & 4.0 & 0.2 & 3.9 & 0.2 \\
\hline Building & 4.5 & 0.1 & 3.0 & 0.0 \\
\hline Retail, foodstuffs and hostelries & 9.6 & 9.8 & 2.2 & 3.8 \\
\hline Domestic service & 5.1 & 58.6 & 1.6 & 23.2 \\
\hline Prof., clerical and local government & 4.2 & 2.5 & 0.6 & 0.3 \\
\hline Armed forces & 0.4 & n.a. & 0.2 & n.a. \\
\hline
\end{tabular}


Victorian towns and cities offered greater employment opportunities to young, unmarried, females than did rural districts and this fact was partly reflected in a higher ratio of females to males among urban populations. In 1851, London contained 223,753 females aged 10-19 compared with only 206,310 males. ${ }^{16}$ Much of the migration of young females to London was directed in search of work in the diverse domestic service sector. Domestic service was popular because it offered accommodation and a wage sufficient to establish a young migrant in a town or city. Young females were less attracted by the long periods of training and lower pay associated with skilled occupations. ${ }^{17}$ In 1851 , general domestic service formed the most popular occupation for London females aged 10-14 (Table 2). In England and Wales (exclusive of London) child domestic servants (i.e. children aged 10-14 in one of the six domestic service categories or employed as charwomen, washerwomen or manglers) formed about 23 per cent of all occupied females aged 10 to 14 whilst in London the comparable figure was nearly 59 per cent. ${ }^{18}$ Concentrations of domestic servants were even higher in Westminster and the City of London where the employment of servants was four to five times the national per capita average. ${ }^{19}$ Nonetheless, the age structure of metropolitan servants was much older than in the rest of England and Wales and this probably reflects a larger proportion of older migrant females in the London domestic sector. General domestic servants in London aged below 20 formed only 33 per cent of the total of female servants compared with 42 per cent in the rest of England and Wales (Table 3). The most youthful domestic service occupation was domestic nurse (the second most numerous discrete category of domestic labour for girls) in which the proportion of the labour force aged 10 to 14 in the rest of England and Wales was more than two and a half times that of the metropolis (Table 3).

Table 3. Domestic Service Occupations. Numbers and proportions employed by age-group, 1851 .

\begin{tabular}{|l|l|l|l|l|l|l|l|l|l|}
\hline & \multicolumn{5}{|l|}{ numbers } & \multicolumn{3}{l|}{$\begin{array}{l}\text { of labour } \\
\text { force }\end{array}$} \\
\hline & Total & $5-9$ & $10-14$ & $15-19$ & $5-9$ & $10-14$ & $15-19$ \\
\hline London & 121215 & 47 & 6424 & 32994 & 0.0 & 5.3 & 27.2 \\
\hline Domestic Servant (General) & 12211 & 0 & 2 & 250 & 0.0 & 0.0 & 2.0 \\
\hline Domestic Servant (Housekeeper) & 5503 & 0 & 0 & 34 & 0.0 & 0.0 & 0.6 \\
\hline Domestic Servant (Cook) & 12996 & 1 & 138 & 2306 & 0.0 & 1.1 & 17.7 \\
\hline Domestic Servant (Housemaid) & 1290.1 & \\
\hline Domestic Servant (Nurse) & 7716 & 9 & 666 & 1980 & 0.1 & 8.6 & 25.7 \\
\hline Domestic Servant \\
(Inn Servant)
\end{tabular}




\begin{tabular}{|l|l|l|l|l|l|l|l|l|}
\hline $\begin{array}{l}\text { Washerwoman, } \\
\text { Mangler etc. }\end{array}$ & 36442 & 3 & 203 & 1892 & 0.0 & 0.6 & 5.2 \\
\hline Total & 213207 & 61 & 7590 & 40947 & 0.0 & 3.6 & 19.2 \\
\hline England and Wales, minus London & 453947 & 713 & 37383 & 151716 & 0.2 & 8.2 & 33.4 \\
\hline Domestic Servant (General) & 41145 & 0 & 0 & 822 & 0.0 & 0.0 & 2.0 \\
\hline Domestic Servant (Housekeeper) & 41798 & 0 & 2 & 1535 & 0.0 & 0.0 & 4.8 \\
\hline Domestic Servant (Cook) & 36889 & 1 & 858 & 9198 & 0.0 & 2.2 & 24.9 \\
\hline Domestic Servant (Housemaid) & 28221 & 489 & 6297 & 7551 & 1.7 & 22.3 & 26.8 \\
\hline Domestic Servant (Nurse) & 26348 & 1 & 1965 & 9661 & 0.0 & 7.5 & 36.7 \\
\hline $\begin{array}{l}\text { Domestic Servant } \\
\text { (Inn Servant) }\end{array}$ & 42122 & 0 & 113 & 1187 & 0.0 & 0.3 & 2.8 \\
\hline Charwoman & 757504 & 1197 & 47319 & 187222 & 0.2 & 6.2 & 24.7 \\
\hline Washerwoman, & 3 & 705 & 5552 & 0.0 & 0.7 & 5.7 \\
\hline Mangler etc. & 37034 & & & & & & & \\
\hline
\end{tabular}

Source: as tables 1 and 2 .

10 Young servants were dispersed widely throughout urban society. The popular literary stereotype of the large upper-middle-class household employing several servants was exceptional in the mid-nineteenth century and the majority of servant-employing households employed only a single 'maid-of-all-work'. ${ }^{20}$ Unfortunately, apart from a few autobiographies, diaries and letters, little evidence of the working conditions and pay of solitary child and adolescent servants has survived. ${ }^{21}$ It seems clear however that many servants came from poorer households.

11 Errand and message running was by far the largest and most youthful occupation for males and the pre-eminence of this occupation cannot be overstated. Although London contained only 11 per cent of the English and Welsh population of 10 to 14 year-olds it comprised 27 per cent of child messengers and porters in that age group. Indeed, the absolute number of male messengers and porters aged 10-14 in the metropolis was more than ten times greater than the next most numerous occupation (Appendix, Table A.2). The category of messengers and porters was derivative of a wider variety of 'connective' services. It is doubtful, for example, that the small proportion (less than one per cent) of working children aged 10-14 recorded with the designation 'shopkeeper' was an accurate reflection of child employment in the retail shop sector and it is most likely that such children were tabulated by the census checkers along with messengers and porters. Despite their overwhelming domination of the London child labour market, however, few very young children were employed as errand runners. James Greenwood, the prominent 
nineteenth-century writer on the metropolitan working class, suggested that children were generally placed as errand boys only after reaching the age of $10 .{ }^{22}$ This observation is borne out by the census statistics, which suggest that only a half per cent of male messengers was aged below 10 whilst 32 per cent were aged 10 to 14 . In common with female domestic servants, male errand runners in London tended to be older than elsewhere: only a third of the total of metropolitan male messengers and porters were aged 10-14 compared with a half in the rest of England and Wales (Table 4). ${ }^{23}$ Mayhew, in his discussion of errand runners, actually provided an underestimate of their number, suggesting that England and Wales as a whole contained a total of 24,205 male porters, messengers and errand boys and that about a fifth 'were lads under 20 years of age. ${ }^{24}$ In fact, the 1851 census disclosed a total of 88,950 of which 59 per cent were aged below $20 .{ }^{25}$ The census also included a category for carmen, carriers, carters and draymen who numbered 43,710 and of whom only about 12 per cent were aged below twenty. However, even if all the 'connective' occupations are aggregated, the age-structure still remains lower than Mayhew's estimates. Nearly a third of the total of male porters, messengers, errand boys, carmen, carriers, carters and draymen in England and Wales in 1851 was aged below 20.

Table 4. Messengers and Porters. Numbers and proportions employed by age group, 1851.

\begin{tabular}{|l|l|l|l|l|l|l|l|}
\hline & \multicolumn{3}{|l|}{ numbers } & \multicolumn{3}{l|}{ \% of labour force } \\
\hline & Total & $5-9$ & $\mathbf{1 0 - 1 4}$ & $\mathbf{1 5 - 1 9}$ & $5-9$ & $\mathbf{1 0 - 1 4}$ & $\mathbf{1 5 - 1 9}$ \\
\hline Males & & & & & & & \\
\hline London & 33059 & 155 & 10472 & 9085 & 0.5 & 31.7 & 27.5 \\
\hline $\begin{array}{l}\text { England and Wales } \\
\text { (minus London) }\end{array}$ & 55891 & 2003 & 27658 & 11971 & 3.6 & 49.5 & 21.4 \\
\hline Females & 262 & 8 & 75 & 32 & 3.1 & 28.6 & 12.2 \\
\hline London & 3308 & 637 & 1863 & 440 & 19.3 & 56.3 & 13.3 \\
\hline $\begin{array}{l}\text { England and Wales } \\
\text { (minus London) }\end{array}$ & & & & & & & \\
\hline
\end{tabular}

Note: males enumerated 'messenger, porter (not govt.)'; females, 'employed about messages'.

Source: as tables 1 and 2 .

In 1851, about a quarter of all occupied London children were in some kind of small workshop, handicraft or other manufacturing. These children were a major concern for social investigators. ${ }^{26}$ Greenwood derided 'the sweaters and slop-factors' who exploited children for their dexterity and cheapness of labour but who cast them adrift when they grew older and more expensive to employ. ${ }^{27}$ The drift towards deskilling in the London workshop trades and the employment of greater numbers of women and children in small manufactures was well established by the mid-nineteenth century. ${ }^{28}$ Much of the concern about sweated labour arose from long hours and harmful working conditions and from the use of piecework where wages were determined entirely by the amount of work 
performed. ${ }^{29}$ Among the most important of the workshop and domestic manufactures that employed children was artificial flower making in which about 19 per cent of its exclusively female labour force were aged below fifteen. ${ }^{30}$ Similarly, the male occupation of paper staining had about 18 per cent of its labour force below fifteen, making it the second most youthful occupation in the metropolis (Appendix, Table A.2). ${ }^{31}$ Classification of children's informal street trading was also virtually impossible for the census takers and the summary tables contain no separate category for street vendors. As Mayhew observed in the mid-century, there was no particular street-trading activity in which children predominated and the objects traded included

money-bags, lucifer-match boxes, leather straps, belts, firewood... fly-papers, a variety of fruits, especially nuts, oranges, and apples; onions, radishes, watercresses, cut flowers and lavender... sweet-briar, India rubber, garters... toys of the smaller kinds, cakes, steel pens and penholders with glass handles, exhibition medals and cards, gelatine cards, glass and other cheap seals, brass watch-guards, chains and rings; small tin ware, nutmeg-graters... iron skewers, fuzees [largeheaded matches], shirt buttons, boot and stay-laces... cotton bobbins, Christmasing (holly and other evergreens at Christmastide), May-flowers, coat-studs, top-pottery, blackberries, groundsel and chickweed, and clothes'-pegs... Independently of the vending of these articles, there are many other ways of earning a penny among the street boys: among them are found - tumblers, mud-larks, water-jacks, Ethiopians, ballad-singers, bagpipe boys, the variety of street musicians (especially Italian boys with organs), Billingsgate boys or young "roughs", Covent Garden boys, porters, and shoeblacks. ${ }^{32}$

13 Where sufficient capital existed, children bought cat and dog meat from local knackers' yards for sale from their own dog-carts. In some cases, urban child occupations amounted to little more than begging. A government report of 1840 noted, 'A boy is told to follow a gentleman on horseback or in a gig till he stops and requires some one to hold his horse; another has a basket of oranges or nuts put into his hands, or, perhaps, a bundle of children's story books to sell; a third has a besom given him to sweep a crossing'. ${ }^{33}$

Other individual occupations enjoyed a higher profile. Chimney-sweeps occupy a prominent position as a result of vigorous campaigning by figures such as Jonas Hanway in the eighteenth century and by Lord Shaftesbury and Charles Kingsley in the nineteenth. ${ }^{34}$ By the mid-nineteenth century, however, their number was relatively small compared with children in other metropolitan trades and services. Hanway estimated that in 1785 there had been 400 to 550 climbing boys in London and an estimate from seven years later put their number at 500 . The number of sweeps' apprentices aged below ten in London in 1841 was estimated by Mayhew to have been $370 .{ }^{35}$ According to the census of 1851, however, there were 1,107 male sweeps aged below fifteen in England and Wales as a whole: of these, 52 were in London and only four sweeps were enumerated below the age of ten. Child sweeps actually appear at $68^{\text {th }}$ in a ranking of male children between the ages of 10 and 14 employed in the metropolis in 1851. Although the number of London sweeps was very small, the figures again suggest that the metropolis had a tendency towards an older labour force (Table 5).

Table 5. Chimney sweeps: numbers and proportions employed by age-group, 1851 .

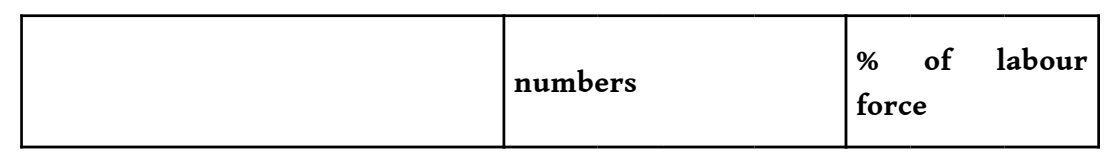




\begin{tabular}{|l|l|l|l|l|l|l|l|}
\hline & Total & $5-9$ & $10-14$ & $15-19$ & $5-9$ & $10-14$ & $15-19$ \\
\hline London & 1179 & 4 & 48 & 108 & 0.3 & 4.1 & 9.2 \\
\hline England and Wales (minus London) & 5012 & 179 & 876 & 830 & 3.6 & 17.5 & 16.6 \\
\hline
\end{tabular}

Note: No females tabulated.

Source: As tables 1 and 2.

There was an exceptionally low relative level of child employment in mid-nineteenth century London. Recorded child employment in the metropolis at ages 10 to 14 was about 45 per cent lower for males and about 50 per cent lower for females compared with the rest of England and Wales. Less than one per cent of London children aged 5-9 and fewer than one in five of those aged 10-14 were enumerated with an occupation in $1851 .^{36}$ Moreover, there is little evidence to suggest that London suffered from underenumeration of child occupations compared with elsewhere. Cross-sectional census statistics collected in Spring tended chiefly to understate seasonal fluctuations in child employment in agricultural districts and the child labour gap between London and the rest of England and Wales would certainly have been much greater during summer and harvest time. ${ }^{37}$

There was also a consistent trend towards an older age-structure among discrete metropolitan occupations compared with the rest of the nation (Table 6).

Table 6. 10-14 year-olds as proportion of totals employed in selected occupations, 1851.

\begin{tabular}{|l|l|l|}
\hline & London & $\begin{array}{l}\text { England \& Wales } \\
\text { (minus London) }\end{array}$ \\
\hline female errand runners & 28.6 & 56.3 \\
\hline female domestic servant (general) & 5.3 & 8.2 \\
\hline female domestic servant (nurse) & 8.6 & 22.3 \\
\hline female domestic servants (aggregate) & 3.6 & 6.2 \\
\hline male errand runners & 31.7 & 49.5 \\
\hline male chimney sweeps & 4.1 & 17.5 \\
\hline male paper stainers & 17.2 & 19.0 \\
\hline
\end{tabular}

Source: as tables 1 and 2

17 In addition, child employment in occupations offering longer-term prospects was exceptionally low. If messengers and errand boys are excluded from the metropolitan labour statistics, the overall participation rate for 10-14 year old males in London falls to 
13 per cent compared with 36 per cent in England and Wales as a whole. ${ }^{38}$ The increasing concentration of urban children in casual and dead-end jobs was identified later in the century when concern over the numbers of male school-leavers entering high-turnover work prior to taking up more permanent jobs or apprenticeships was identified by social commentators. ${ }^{39}$

At the end of the century, 54 per cent of London school leavers became 'errand boys, shop boys, or van boys' and more than 50 per cent of a sample of Glaswegian boys leaving elementary school became milk boys or lorry boys. Reports by the Poor Law Commission and the Board of Education noted:

The results of the large employment of boys in occupations which offer no opportunity of promotion to employment as men are disastrous. The boy, thrown out at 16,17 , or 18 or 20 years of age, drifts into the low-skilled labour market or the army of unemployables. ${ }^{40}$

This study suggests that the origins of that problem lay much earlier in the nineteenth century.

Mid-nineteenth century social inquirers were preoccupied chiefly with the employment of poor children in casual, dangerous or demoralising occupations. Their reports were valuable in highlighting the plight of socially disadvantaged children but they do not reflect the generality of metropolitan child labour. Domestic service, for example (the pre-eminent employer of female child labour in London) was ignored entirely by Mayhew in his commentaries on London labour. ${ }^{41}$ The aggregate occupation statistics presented above offer a partial solution to the preconceptions and biases of social commentary and suggest that child labour had, by the middle of the nineteenth century, become a largely residual activity for metropolitan children. However, much of the detail of localised forms of child labour remains hidden within the prevailing occupational complexity of the metropolis. ${ }^{42}$ As Hobsbawm has argued, in order to understand the changing human geography of London, fragmentary and unsatisfactory sources will need to be more intensively exploited. ${ }^{43}$ This is especially the case with child and juvenile labour.

\section{APPENDIXES}

Table A.1. Top twenty jobs for 10-14 year old females, London, and England and Wales, 1851.

\begin{tabular}{|c|c|c|c|}
\hline & Total & $10-14$ & $\begin{array}{l}\% \text { of } \\
\text { occupation } \\
\text { aged 10-14 }\end{array}$ \\
\hline London: females & & & \\
\hline Domestic Servant (General) & 121215 & 6424 & 5.3 \\
\hline
\end{tabular}




\begin{tabular}{|c|c|c|c|}
\hline Milliner & 43928 & 1021 & 2.3 \\
\hline Domestic Servant (Nurse) & 7716 & 666 & 8.6 \\
\hline Seamstress & 21210 & 564 & 2.7 \\
\hline Artificial Flower-maker & 2730 & 501 & 18.4 \\
\hline Silk manufacture & 8277 & 420 & 5.1 \\
\hline Shoemaker & 7158 & 344 & 4.8 \\
\hline Tailor & 8292 & 260 & 3.1 \\
\hline Others engaged about Publications & 2843 & 222 & 7.8 \\
\hline Washerwoman, Mangler, Laundry-keeper & 36442 & 203 & 0.6 \\
\hline Domestic Servant (Inn Servant) & 5554 & 157 & 2.8 \\
\hline Other Paper Workers, Dealers & 1227 & 145 & 11.8 \\
\hline Domestic Servant (Housemaid) & 12996 & 138 & 1.1 \\
\hline Other Workers, Dealers in Silk & 1435 & 117 & 8.2 \\
\hline Cap-maker & 1277 & 107 & 8.4 \\
\hline Others providing Dress & 2471 & 107 & 4.3 \\
\hline Brush, Broom Maker & 1205 & 230 & 19.1 \\
\hline Others dealing in Wood Furniture & 980 & 76 & 7.8 \\
\hline Embroiderer & 1413 & 76 & 5.4 \\
\hline Employed about Messages & 262 & 75 & 28.6 \\
\hline England and Wales minus London: females & & & \\
\hline Domestic Servant (General) & 453947 & 37383 & 8.2 \\
\hline Cotton manufacture & 194456 & 29027 & 14.9 \\
\hline Farmer's, Grazier's Daughter, Granddaug., etc. & 136169 & 27689 & 20.3 \\
\hline Farm Servant (in-door) & 99111 & 16342 & 16.5 \\
\hline Worsted manufacture & 51176 & 10581 & 20.7 \\
\hline Silk manufacture & 60065 & 10113 & 16.8 \\
\hline Lace manufacture & 51634 & 8587 & 16.6 \\
\hline
\end{tabular}




\begin{tabular}{|l|l|l|l|}
\hline Woollen Cloth manufacture & 45371 & 7329 & 16.2 \\
\hline Domestic Servant (Nurse) & 28221 & 6297 & 22.3 \\
\hline Straw Plait manufacture & 27416 & 5040 & 18.4 \\
\hline Milliner & 190412 & 5027 & 2.6 \\
\hline Glover (material not stated) & 24588 & 3342 & 13.6 \\
\hline Hose, Stocking, manufacture & 25298 & 3151 & 12.5 \\
\hline Agricultural Labourer (out-door) & 44199 & 2702 & 6.1 \\
\hline Flax, Linen manufacture & 13161 & 2548 & 19.3 \\
\hline Earthenware manufacture & 10693 & 2135 & 20.0 \\
\hline Domestic Servant (Inn Servant) & 26348 & 1965 & 7.5 \\
\hline Employed about Messages & 3308 & 1863 & 56.3 \\
\hline Shoemaker & 22094 & 1853 & 8.4 \\
\hline Nail manufacture & 9961 & 1337 & 13.4 \\
\hline
\end{tabular}

Sources: as tables 1 and 2.

Table A.2. Top twenty jobs for 10-14 year old males, London, and England and Wales, 1851.

\begin{tabular}{|l|l|l|l|}
\hline & Total & $\mathbf{1 0 - 1 4}$ & $\begin{array}{l}\text { occupation } \\
\text { aged 10-14 }\end{array}$ \\
\hline London males & & & \\
\hline Messenger, Porter (not Govt.) & 33059 & 10472 & 31.7 \\
\hline Domestic Servant (General) & 20348 & 958 & 4.7 \\
\hline Shoemaker & 30855 & 932 & 3.0 \\
\hline Labourer (branch undefined) & 50173 & 833 & 1.7 \\
\hline Printer & 10365 & 498 & 4.8 \\
\hline Commercial Clerk & 16420 & 477 & 2.9 \\
\hline Butcher & 9586 & 414 & 4.3 \\
\hline Tailor & 22479 & 403 & 1.8 \\
\hline
\end{tabular}




\begin{tabular}{|c|c|c|c|}
\hline Silk manufacture & 7487 & 340 & 4.5 \\
\hline Carpenter, Joiner & 23453 & 270 & 1.2 \\
\hline Domestic Servant (Inn Servant) & 8129 & 266 & 3.3 \\
\hline Paper-stainer & 1438 & 248 & 17.2 \\
\hline Baker & 11580 & 240 & 2.1 \\
\hline Others dealing in Drinks, Stimulants & 4796 & 238 & 5.0 \\
\hline Plasterer & 4378 & 231 & 5.3 \\
\hline Law Clerk & 5670 & 229 & 4.0 \\
\hline Painter, Plumber, Glazier & 15369 & 200 & 1.3 \\
\hline Draper & 7466 & 194 & 2.6 \\
\hline Ropemaker & 1469 & 168 & 11.4 \\
\hline Grocer & 7853 & 163 & 2.1 \\
\hline England and Wales minus London: males & & & \\
\hline Agricultural Labourer (out-door) & 905397 & 72965 & 8.0 \\
\hline Farmer's, Grazier's, Son, Grandson, etc. & 142952 & 28404 & 19.9 \\
\hline Messenger, Porter (not Govt.) & 55891 & 27658 & 49.5 \\
\hline Farm Servant (in-door) & 189100 & 25664 & 13.6 \\
\hline Cotton manufacture & 176616 & 25593 & 14.5 \\
\hline Coal-miner & 183352 & 23038 & 12.6 \\
\hline Labourer (branch undefined) & 274421 & 12645 & 4.6 \\
\hline Woollen Cloth manufacture & 76482 & 9234 & 12.1 \\
\hline Worsted manufacture & 51386 & 9048 & 17.6 \\
\hline Shoemaker & 180145 & 8768 & 4.7 \\
\hline Silk manufacture & 36111 & 5531 & 15.3 \\
\hline Iron manufacture & 64055 & 5303 & 8.3 \\
\hline Domestic Servant (General) & 53975 & 4268 & 7.9 \\
\hline Earthenware manufacture & 22855 & 3992 & 17.5 \\
\hline
\end{tabular}




\begin{tabular}{|l|l|l|l|}
\hline Tailor & 92992 & 3961 & 4.3 \\
\hline Hose, Stocking, manufacture & 33551 & 3277 & 9.8 \\
\hline Blacksmith & 86407 & 2993 & 3.5 \\
\hline Carpenter, Joiner & 132658 & 2574 & 1.9 \\
\hline Mason, Paviour & 73110 & 2421 & 3.3 \\
\hline Brickmaker & 26321 & 2187 & 8.3 \\
\hline
\end{tabular}

Sources: as tables 1 and 2.

\section{NOTES}

1. See T.C. BARKER, 'Business as Usual? London and the Industrial Revolution', History Today, 39 (1989). Important exceptions include D.R. GREEN, From Artisans to Paupers : Economic Change and Poverty in London, 1790-1870 (Aldershot, 1995); L.D. SCHWARZ, London in the Age of Industrialisation : Entrepreneurs, Labour Force and Living Conditions, 1700-1850 (Cambridge, 1992); G.S. JONES, Outcast London (Harmondsworth, 1984); E.J. HOBSBAWM, 'The Nineteenth Century London Labour Market', in Centre for Urban Studies (ed.), Report No.3, London : Aspects of Change (1964); P.G. HALL, The Industries of London since 1861 (1962); P.G. HALL, 'Industrial London : A General View', in J.T. COPPOCK \& H.C. PRINCE (eds.), Greater London (1964).

2. Anna Davin has produced a number of pioneering works on the London child labour market. A. DAVIN, 'Working or Helping? London working-class children in the domestic economy', in Households in the World Economy, ed. J. SMITH, I. WALLERSTEIN \& H. EVERS (1984) and A. DAVIN, Growing up Poor: Home, School and Street in London, 1870-1914 (1996).

3. H. MAYHEW, London Labour and the London Poor (1852; 1865 edn., Harmondsworth, 1985, ed. V. NEUBURG); H. MAYHEW, Morning Chronicle Survey of Labour and the Poor : The Metropolitan Districts (Horsham, 1982); J. GREENWOOD, The Seven Curses of London (1869; Oxford 1981 edn. Ed. J. Richards); T. WRIGHT, Some Habits and Customs of the Working Classes (1867); J. PARR, Labouring Children : British Immigrant Apprentices to Canada, 1869-1924 (1980); G. WAGNER, Barnardo (1979); G. WAGNER, Children of the Empire (1982).

4. Cited in D.R. GREEN, op. cit., p. 63.

5. G.S. JONES, op. cit., p. 31.

6. E.J. HOBSBAWM, op. cit., p. 13; P.G. HALL, in J.T. COPPOCK \& H.C. PRINCE, op. cit., pp. 229-235.

7. The serious health effects of match making had only become a matter of debate among the medical profession during the later 1840s. PP 1863, XVIII, R.C. on Children's Employment, $1^{\text {st }}$ Report, pp. xlviii, 41-2.

8. E.J. HOBSBAWM, op. cit., p. 15; C. NARDINELLI, Child Labor and the Industrial Revolution (Indiana, 1990), passim; O. SAITO, 'Labour Supply Behaviour of the Poor in the English Industrial Revolution', Journal of European Economic History, 10 (1981).

9. E. HIGGS, Making Sense of the Census (HMSO, 1989), p. 78.

10. P.M. TILLOTT, 'Sources of Inaccuracy in the 1851 and 1861 Censuses', Nineteenth-Century Society : Essays in the use of Quantitative Methods for the Study of Social Data, ed. E.A. WRIGLEY (Cambridge, 1972), p. 124; Hill suggests that the term 'domestic servant' may only have been invented in the nineteenth century for the first occupational censuses. B. HILL, Servants : English Domestics in the Eighteenth Century (Oxford, 1996), p. 13. 
11. A small number of discrepancies exist between the London and the national tables. For example, there were no male 'boat and bargemen' aged 10-14 recorded in the tables for England and Wales as a whole in 1851 whilst 87 were counted in the London tables alone. Similarly, 31 females aged 10-14 were recorded as 'other teachers' in the London tables but none was recorded in England and Wales tables. Such discrepancies are so small as to suggest a good general numerical correspondence between London and national tables.

12. Numbers of London children (by individual occupations) were subtracted from the totals for England and Wales in order to deal with the obvious problem of counting the same children twice. Excluded from those 'employed' are sons, daughters, and other relatives where no occupation designation was provided in the tables (this clearly understates the numbers of children at work in the domestic sphere), scholars, persons of no stated occupations, persons of indefinite occupations, vagrants, paupers, persons of independent means, annuitants, lunatics and prisoners.

13. The issue of child 'unemployment' is discussed in H. CUNNINGHAM, 'The employment and unemployment of children in England c.1680-1851', Past and Present, 126 (1990) and P. KIRBY, 'How many children were "unemployed" in eighteenth and nineteenth-century England?', Past and Present (forthcoming 2004).

14. H. MAYHEW, op. cit., ed. V. NEUBURG, p. 169.

15. The groups below are derivative of the large number of discrete occupations in the summary tables. See P. KIRBY, Child Labour in Britain, 1750-1870 (Basingstoke, 2003), tab.3.1, p. 52, App., pp. 135-140. 'Transport and communications' includes messengers, porters and errand boys. 'Agriculture, animals and fisheries' includes estimates for missing employed kin of farmers. P. KIRBY, "How many children were "unemployed" in eighteenth and nineteenth-century England?', Past and Present (forthcoming 2004). The table assumes that 25 per cent of female general servants worked on farms and that they worked in agriculture 0.5 per cent of their working time. M. ANDERSON, 'Households, Families and Individuals: Some Preliminary Results from the National Sample from the 1851 Census of Great Britain', Continuity and Change, 3 (1988), p. 427. There were no females in the armed forces.

16. P. KIRBY, Child Labour in Britain, 1750-1870 (Basingstoke, 2003), p. 34; PP 1852-53, LXXXVIII, Pt.I, Population Tables II, pp. 10-15.

17. E. ROBERTS, Women's Work, 1840-1940 (Cambridge, 1988), p. 5.

18. In 1851, females in domestic service in England and Wales outnumbered males by about eight to one whereas males in farm service outnumbered females by two to one. A. KUSSMAUL, Servants in Husbandry in Early Modern England (Cambridge 1981), p. 4.

19. L.D. SCHWARZ, 'English servants and their employers during the eighteenth and nineteenth centuries', Economic History Review, $2^{\text {nd }}$ ser., 52 (1999), table 2, p. 242; B. HILL, op. cit., p. 4.

20. In mid-nineteenth-century Rochdale, for example, more than $60 \%$ of servants worked in households containing a single servant. E. HIGGS, Domestic Servants and Households in Rochdale 1851-1871 (1986), p. 57.

21. For example, see H. CULLWICK, The Diaries of Hannah Cullwick : Victorian Maidservant (ed. L. STANLEY 1984); more generally, see the occupational index in J. BURNETT, D. VINCENT \& D. MAYALL (eds.), The Autobiography of the Working Class : An Annotated Critical Bibliography, 1790-1945, 3 vols. (Brighton, 1986-89).

22. J. GREENWOOD, op. cit., p. 40.

23. P. KIRBY, op. cit., p. 68; the comparative figures for Northumberland and industrial Lancashire were $63 \%$ and $38 \%$. The author is grateful to Dr L.M.W. Shaw-Taylor and Prof. E.A. Wrigley for supplying the Northumberland and Lancashire data sheets for males from which these comparative figures were calculated.

24. H. MAYHEW, op. cit., $10^{\text {th }}$ Oct. 1850 , p. 90.

25. PP 1852-53, LXXXVIII, Pt.I, Population Tables II, pp. 10-15. 
26. For example, see the discussion of apprenticeship in T. WRIGHT, op. cit., pp. 83-107.

27. J. GREENWOOD, op. cit., p. 12.

28. One worker observed to Mayhew in the late 1840s, 'A man's own children will soon be the means of driving him from the market altogether, or compelling him to come down to their rate of wages.' D.R. GREEN, op. cit., p. 81.

29. Ibid., p. 77.

30. Greenwood was concerned about the artificial flower-makers with their discoloured teeth and 'chafed and chilblainish appearance about their nostrils' caused by arsenite of copper used in green colouring. J. GREENWOOD, op. cit., p. 12, p.14.

31. A Royal Commission of 1862 reported 420 children below 18 in paper staining in London, which offers a rough fit with the statistic offered by the 1851 census. PP 1863, XVIII, p. lviii. London paper staining was mainly concentrated in block or hand-printing whereas in the other major paper staining district, Lancashire, much greater use was made of machine printing. Of the 25 London paper-staining works visited in 1862, only three used machines as the principal mode of production. Ibid., p. 119. In paper staining, London had slightly fewer children as a proportion of total employed compared with Lancashire: 18 per cent of males in London paper staining were aged below 15 compared with 21 per cent in Lancashire.

32. H. MAYHEW, op. cit., ed. NEUBURG, p. 167.

33. Report on the Condition of the Hand-Loom Weavers, PP 1840, XXIV, (Report of W.E. HICKSON), p. 52.

34. See for example, J. HANWAY, A Sentimental History of Chimney-Sweepers in London and Westminster (1785) and C. KINGSLEY, The Water Babies (1863); see also K.H. STRANGE, Climbing Boys : A Study of Sweeps' Apprentices, 1773-1875 (1982).

35. G.L. PHILLIPS, England's Climbing-Boys : A History of the Long Struggle to Abolish Child Labor in Chimney-Sweeping (Boston, 1949), p. 3.

36. Most of the employed 10-14 age group would be concentrated at ages 13 and 14. P. KIRBY, op. cit., p. 80 .

37. The 1851 census was taken on $30^{\text {th }}$ March. In England and Wales (exclusive of London) 37 per cent of occupied males aged 10-14 were engaged in agriculture, animals and fisheries, compared with fewer than 2 per cent in London (see Table 2).

38. Messengers and errand boys made up 43 per cent of the total of employed 10-14 year olds in London but only 10 per cent in the rest of England and Wales.

39. E.J. URWICK, ed., Studies of Boy Life in our Cities (1904); H. HENDRICK, Images of Youth: Age, Class and the Male Youth Problem (Oxford, 1990); D. FOWLER, The First Teenagers : The Lifestyle of Young Wage-Earners in Interwar Britain (1995), pp. 21-24.

40. R.H. TAWNEY, 'The economics of boy labour', Economic Journal, 19 (1909), pp. 524, 520, 517; The term 'blind alley labour' was coined to describe children in occupations that offered no longterm security. A. GREENWOOD, 'Blind-alley labour', Economic Journal, 22 (1912), p. 309.

41. D.R. GREEN, op. cit., p. 63.

42. For example, no 'percussion cap makers' may be found for either sex in the census summary tables, despite contemporary controversy about their conditions of work. R.C. Children's Employment, $1^{\text {st }}$ Rep., PP 1863, XVIII, pp. 105-118.

43. E.J. HOBSBAWM, op. cit., pp. 18-19; see also A. DAVIN, op. cit. 


\section{ABSTRACTS}

The profusion of services and small trades that characterised the nineteenth-century London labour market makes it extremely difficult to arrive at any general understanding of the work of children and juveniles. This brief study employs published statistical materials and compares children's occupations in the metropolis with the national picture. It argues that London contained exceptionally low levels of children's employment compared with the rest of England and Wales. The preoccupation of metropolitan social observers with working children arose from the fact that child employment in mid-nineteenth century London was a marginal activity associated chiefly with the very poor.

La profusion de services et de petits métiers qui caractérisait le marché du travail londonien au $\mathrm{XIX}^{\mathrm{e}}$ siècle rend difficile toute perception globale du travail des enfants et des adolescents. Ce bref article utilise les statistiques publiées pour comparer les emplois des enfants dans la métropole et dans l'ensemble du pays. Il avance que Londres avait un taux d'emploi des enfants particulièrement bas par rapport à l'Angleterre et au Pays de Galles. L'inquiétude manifestée par les observateurs sociaux à l'égard de l'emploi des enfants à Londres a résulté du fait que c'était, à l'époque, une activité marginale liée essentiellement à la grande pauvreté.

\section{AUTHOR}

\section{PETER KIRBY}

Department of History, University of Manchester 